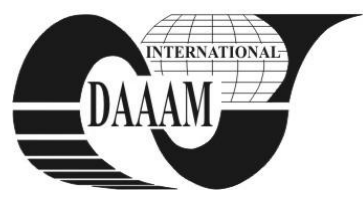

Annals of DAAAM for 2011 \& Proceedings of the 22nd International DAAAM Symposium, Volume 22, No. 1, ISSN 1726-9679 ISBN 978-3-901509-83-4, Editor B. Katalinic, Published by DAAAM International, Vienna, Austria, EU, 2011 Make Harmony between Technology and Nature, and Your Mind will Fly Free as a Bird Annals \& Proceedings of DAAAM International 2011

\title{
COMPARASION OF MACHINABILITY OF BIOCOMPATIBLE MATERIALS USED IN MEDICINE FOR DENTAL IMPLANTS
}

\author{
MRAZOVA, M[ichaela]; STANCEKOVA, D[ana] \& SEMCER, J[an]
}

\begin{abstract}
The main goal of our research is identification and intensification of cutting conditions of commericial pure titanium (cpTi) used for dental implants and compare machinability of different cpTi grades.
\end{abstract}

Key words: machinability, biocompatible materials, biomedicine, hardmachining materials

\section{INTRODUCTION}

Metallic materials, for example, stainless steel, titanium and its alloys, and tantalum are widely used for medical implants in trauma surgery, orthopaedic and oral medicine (Brunette et al., 2001). The material for dental implants is required to be biocompatible, mustn't be toxic and also shouldn't cause allergic reactions. It must have high ultimate strength $R m$ and yield point $R p$ with desirable low density and low modulus of elasticity $E$ (Petruželka et. al., 2006). A problem in the course of the development of metallic biomaterials represents not only their actual or potential toxicity but also their allergenetic potential (Niinomi, 2002). Commercial pure cpTi (Tab.1) stays the preferred material for dental applications (Fig. 1). It is desirable to increase its other mechanical properties without using even potentially toxic or allergenic elements preserving its low value of modulus of elasticity (Petruželka et. al., 2006).

\begin{tabular}{|l|l|l|l|l|l|l|}
\hline & $\mathrm{C}$ & $\mathrm{Fe}$ & $\mathrm{H}$ & $\mathrm{N}$ & $\mathrm{O}$ & $\mathrm{Ti}$ \\
Quality & {$[\%]$} & {$[\%]$} & {$[\%]$} & {$[\%]$} & {$[\%]$} & {$[\%]$} \\
\hline Grade & $\max$. & $\max$. & $\max$. & $\max$. & $\max$ & to \\
2 & 0,08 & 0,3 & 0,015 & 0,03 & 0,25 & 100 \\
\hline Grade & max. & $\max$. & $\max$. & $\max$. & $\max$ & to \\
4 & 0,08 & 0,5 & 0,015 & 0,05 & 0,4 & 100 \\
\hline
\end{tabular}

Tab. 1. Chemical composition of Ti based on ISO $5832-2$

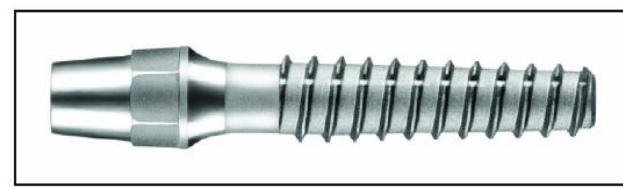

Fig. 1. Dental implant (Hrušák et al., 2006)

\section{MACHINABILITY OF TITANIUM SAMPLES}

Medical device manufacturers face tough challenges. Their customers are demanding ever smaller, more complex parts produced with extraordinary accuracies from hardmachining materials such as titanium. During the machining of titanium materials is very important the correct choice of cutting material, tool geometry, cutting conditions and cutting environment. The Department of Machining and Manufacturing Technology, University of Zilina, Slovakia, supported by the grant agency VEGA, on the basis of developments and the progress of new materials and increasingly demanding requirements for accuracy, we started by identifying the basic technological conditions of machining titanium by turning, using a replaceable cutting edges of hard metal (Fig.3, Tab.2), and intensification of cutting conditions on machining cylindrical samples of commercially pure titanium with a diameter $\mathrm{d}=4$ and $5 \mathrm{~mm}$ (Fig.2).

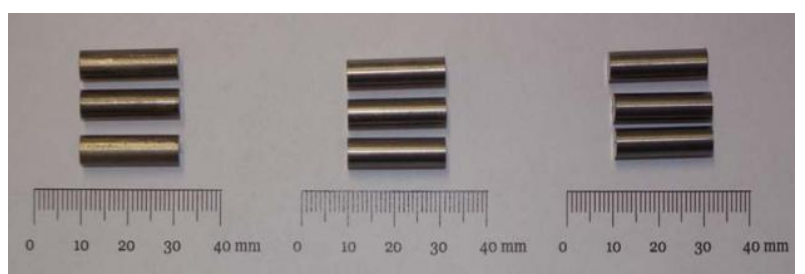

Fig. 2. a) sample of TiGr2 b) TiGr4 $\quad$ c) TiGr5
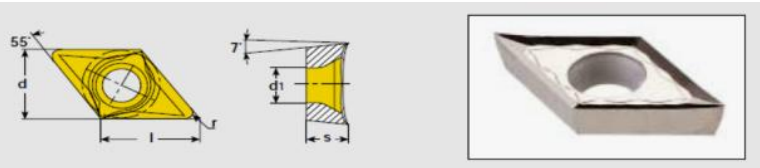

Fig. 3. Replaceable cutting edge DCGT 070204

\begin{tabular}{|l|l|l|l|l|l|}
\hline & l & d & s & d1 & r \\
\hline $\begin{array}{l}\text { DCGT } \\
\text { 070204 }\end{array}$ & 7,75 & 6,35 & 2,38 & 2,8 & 0,4 \\
\hline
\end{tabular}

Tab. 2. Dimensional parameters of the cutting plate

DCGT 070204 in millimetres.

In the experimental measurements were used dry environment as recommended by the manufacturer of cutting tools designed for hard turning, in order to avoid cracking due to thermal shocks. After evaluating the results, kinetic, dynamic and microgeometric machinability and also machinability in terms of chip's shape showed that the most appropriate cutting conditions for turning titanium samples at a constant speed $n=$ $2200 \mathrm{~m} \cdot \mathrm{min}^{-1}$, are $a_{p}=0,2 \mathrm{~mm}$ (depth of cut) $f=0,035 \mathrm{~mm}$ (feed).

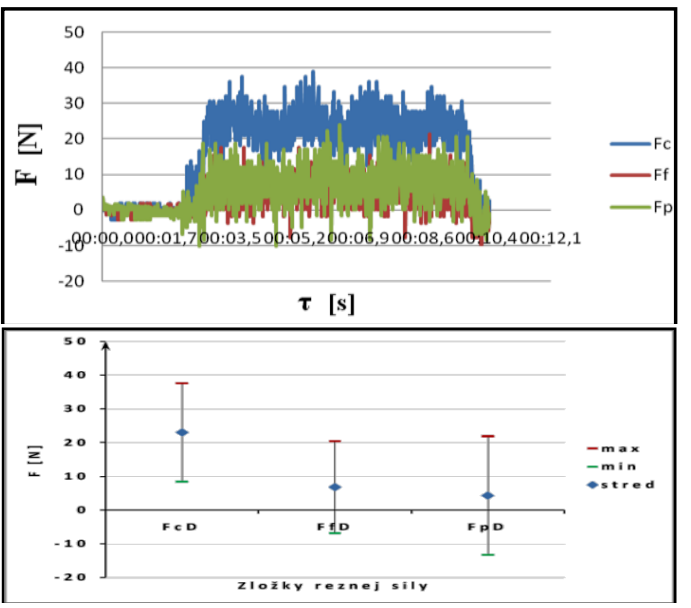

Fig. 4. An example of cutting forces waveform elements, with the cutting conditions: $a_{p}=0,2 \mathrm{~mm}, \mathrm{f}=0,035 \mathrm{~mm}$, the material TiGr4 and also their dynamic elements. 

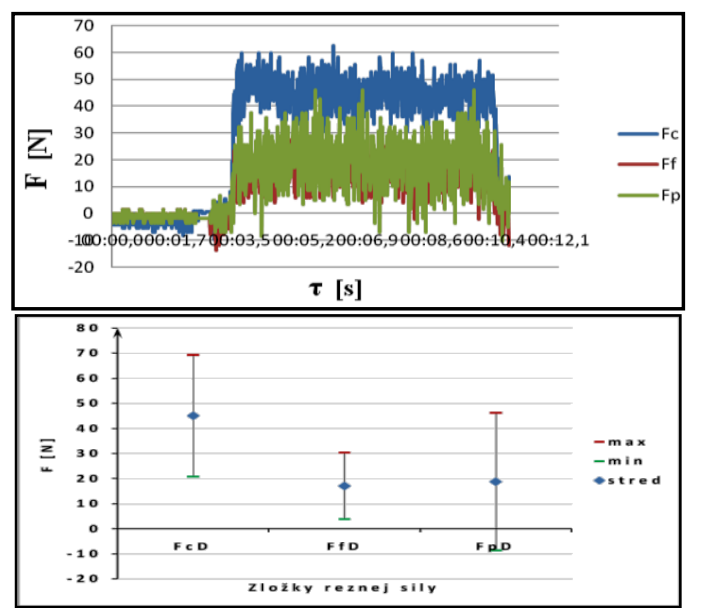

Figure 5: An example of cutting forces waveform elements, with the cutting conditions: $a_{p}=0,6 \mathrm{~mm}, f=0,035 \mathrm{~mm}$, the material TiGr2 and also their dynamic elements.

Static values of cutting force elements for both the cutting edges with increasing feed were rising. The biggest impact on the size of elements of cutting forces is the depth of cut $a_{p}$. Replacing the edge did not significantly affect the value of static force elements (Fig. 4, 5). Dynamic machinability of considered material did not depend on the type of cutting edge. Compared to the reference material (TiGr2) the material TiGr4 shows the class better and TiGr5 equally machined (Fig. 6). In point of view of cutting material was designated as suitable cutting plate DCGT 070204 ER-SI (polished), which is much more resistant to thermal shock in the cutting zone and has a greater wear resistance of $70-80 \%$ as a cutting plate DCGT 070204 REX (coated).

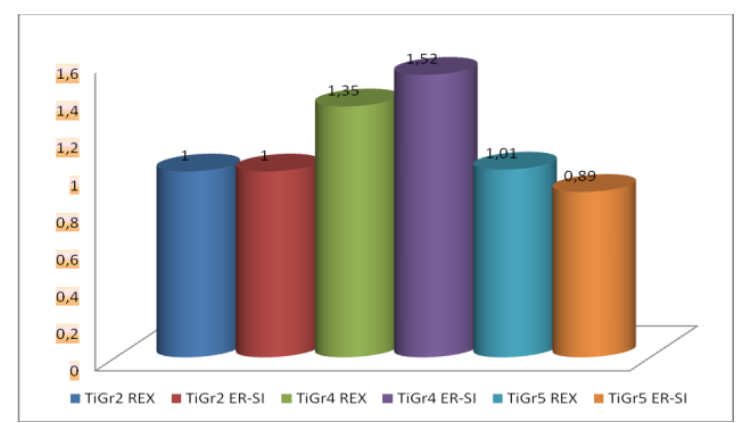

Figure 6: Graphical representation of the dynamic machinability of compared materials

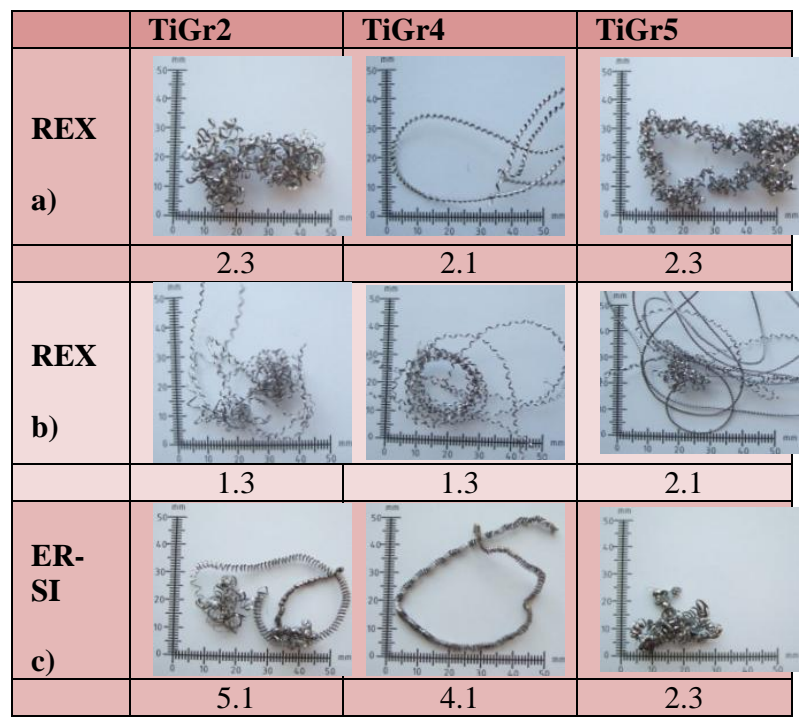

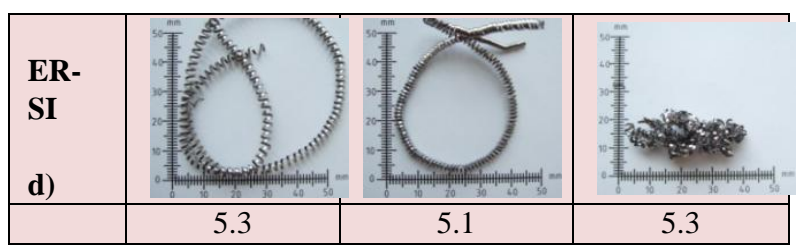

Table 3: Example of chip shapes, on which was measurement evaluated.

The cutting edge DCGT 070204 ER-SI, as regards the shape of chip, in all experiments was appropriate than plate DCGT 070204 REX. This is thanks to the polished surface, which causes more resistance material, and the better chip removal (Tab. 3).

\section{CONCLUSION}

Commercialy pure titanium is a hardmachining material and need to be searching long time to get satisfactory results. Our research si at beginning, but from the present results indicate that the most appropriate cutting conditions for turning titanium samples at a constant speed $n=2200 \mathrm{~m} \cdot \mathrm{min}^{-1}$, are $a_{p}=$ $0,2 \mathrm{~mm}$ (depth of cut) $f=0,035 \mathrm{~mm}$ (feed). The cpTi grade 4 have the best machinability from the searching grades and cutting edge DCGT 070204 ER-SI is more suitable for machining these materials.

On the basis of a grant from the Grant Agency VEGA Department of machining and manufacturing technology attempt to identify the cutting parameters in nanostructured titanium as well as in commercial pure titanium and compare them with each other, and thus continue to research materials for dental implants.

\section{REFERENCES}

D.M. Brunette, P. Tengvall, M. Textor, P. Thomsen: Titanium in Medicine (Springer-Verlag Berlin Heidelberg, Germany, 2001)

Petruželka,J. - Dluhoš,L. - Hrušák,D. - Sochová,J.: Nanostructured titanium - application in dental implants. Sborník vědeckých prací Vysoké školy báňské-Technické univerzity Ostrava, ISBN 80-248-1142-1, No.1/2006, Vol. 52, pp. $177-186$

NIINOMI, M. Recent metallic materials for Biomedical Applications. Metallurgical and materials Transactions A. march 2002. vol. 33 A. pp. 477-486

Valiev R.Z., Semenova I.P., Dluhoš L., a kol.: Nanostructured Titanium for Biomedical Application. Advanced Engineering Materials 2008,10, No. 8, Weinheim, IF 1,463.

Hrušák, D. - Dluhoš,L. - Petruželka, J.: Nanoimplantát implantát 3. tisiciletí. StomaTeam CZ, 2006,2, ISSN 1214$147 \mathrm{X}$, pp. 2-3

Rack, Henry J.(2008). Recent Advances in Titanium Alloys for Biomedical Device Application, Professor at Clemson University, School of Materials Science and Engineering. (www.timplant.cz)

Czán, A. - Neslušan, M. (2005): Trieskové obrábanie t’ažkoobrábatelných materiálov. Žilina: EDIS, 174 s. ISBN 80-969395-2-1

Benes, J: Machining titanium implants, American Machinist, 17.8.2006

***http://www.martikan.eu Accessed on:2011-08-15

***http://www.timplant.cz Accessed on:2011-08-15 